\title{
COOPERATION OF ENTERPRISES WITH SECONDARY VOCATIONAL SCHOOLS: COMPARATIVE ANALYSIS IN THE CONTEXT OF THE CZECH REPUBLIC AND SLOVAKIA
}

\author{
Michal Hanák ${ }^{1}$, Katarína Ižová ${ }^{2}$, Kateřina Bočková ${ }^{3}$
}

\begin{abstract}
The presented paper deals with the mutual cooperation of secondary vocational schools and enterprises within the framework of the dual education system, respectively of the social partnership in the conditions of Czech Republic and Slovakia. It has a theoretically - empirical character. In the theoretical part we focused on defining the terms we work with and the empirical part focuses on the questionnaire survey, in which we find out the views of pupils, teachers and enterprise representatives on the real possibilities and possible benefits of cooperation between schools and business sector. In the framework of the questionnaire survey we focused on the Zlín region in the Czech Republic and the Žilina region in Slovakia, while the selection of the area was random. Using two self-designed questionnaires, we found out what pupils, teachers and enterprise representatives consider to be beneficial for the cooperation and what is necessary to be improved. Based on the findings, we have drawn conclusions and suggested measures to improve the current situation. We found that the social partnership in the Czech Republic is at a higher level and more secondary vocational schools are involved than the dual education system in Slovakia.
\end{abstract}

JEL Classification Numbers: I25, DOI: https://doi.org/10.12955/peb.v1.24

Keywords: Dual education. Social partnership. Cooperation. Benefits and improvements.

\section{Introduction}

Recently, the strengthening of the practical component of education has been mentioned as the main priority within the educational process. However, this cannot be done well unless there is a change in the framework education programs and other support measures to support vocational training and the cooperation of secondary vocational schools and enterprises in their vicinity. It is essential that framework education programs are based on the needs of individual companies. This would affect employers' vocational training. It should be noted that without a regular and solid basis of predicting labor market needs, meaningful educational content, staffing, building personal relationships and securing finance, partial changes will not bring about a shift.

The dual education or social partnership system is exceptional in that it establishes a partnership between the employer and the pupil, which is defined in the form of a learning agreement which regulates the rights and obligations of the parties in relation to the practical teaching of the pupil. Another important aspect of this system of education is the relationship between the employer and the school on a contractual basis in the form of a dual education contract, which regulates in particular the scope, conditions and coordination of the pupil's vocational training with the learning agreement.

We believe that a closer understanding of the issue will provide a more comprehensive view of the current form of education in the context of school-business partnerships, which also significantly affects the quality of training for young people. The quality of preparation is related to the employability of school graduates on the labor market. The quality of the school is also reflected in the quality of preparation and can be a guide for those who decide on the choice of secondary school. The education system in Slovakia and the Czech Republic has also undergone significant changes in connection with school reforms, which have brought major changes in the educational world. At present, the position of schools is different from the past, and autonomy enables schools to decide more about the form of the education process. This brings the possibility of cooperation with enterprises. Active cooperation of educational institutions and subjects from the world of work and business is then a necessary condition for the development of quality education and quality vocational training in accordance with the conditions of the market working environment. Schools have the opportunity to prepare their pupils as best they can.

Based on the above, we present a view of the cooperation of secondary vocational schools and enterprises in their neighborhood and point out the differences and common features of this cooperation in the Czech Republic and Slovakia, which is proved by the results of the questionnaire survey.

\footnotetext{
${ }^{1}$ DTI University, Department of School Didactics, Dubnica nad Váhom, Slovakia, hanak@dti.sk

${ }^{2}$ DTI University, Department of Management and Economics, Dubnica nad Váhom, Slovakia, izova@dti.sk

${ }^{3}$ DTI University, Department of Management and Economics, Dubnica nad Váhom, Slovakia, bockova@dti.sk
} 


\section{The Methodology Used}

\section{Objectives}

The primary objective of the paper is to analyze the possibilities of cooperation between enterprises and secondary vocational schools in the Zlín Region in the Czech Republic and the Žilina Region in Slovakia. While this cooperation is understood in the Czech Republic as a social partnership between school and enterprise, in Slovakia we are talking about the dual education system.

The primary objective was divided into the following secondary objectives, which we tried to achieve and fulfill their content in individual parts of the presented paper. The first secondary objective is to specify and define the main concepts related to dual education, respectively a social partnership representing the cooperation of enterprises with secondary vocational schools. The second secondary objective is to demonstrate the results of a questionnaire survey carried out in the Zlín and Žilina regions focused on the possibilities of cooperation between enterprises and schools.

\section{Material and Methods}

In order to achieve the set objectives, the paper is divided into two basic parts - theoretical and empirical. In the theoretical part, which is focused on the definition of basic concepts related to dual education in Slovakia and the social partnership of schools and enterprises in the Czech Republic, we used mainly the method of comparison, by which we compared the opinions of different authors on the defined issues. We based this primarily on Slovak and Czech information sources; we also used the current legislative framework. In the second, empirical part of the paper, we used our own questionnaire survey, which was used to find out the opinions of pupils, teachers and representatives of selected enterprises on the benefits of cooperation of enterprises and secondary vocational schools in preparing pupils for the labor market. We used two questionnaires of our own design, the first contained 18 closed items, where the respondent could choose one of the options. The second questionnaire contained 5 closed items, with three of which the respondent could choose more answers and 4 open items.

In processing the questionnaires, we used simple mathematical operations such as addition, total absolute number and conversion of absolute number of answers found to their percentage. These mathematical operations were sufficient for finding out the opinions and real state in the given field of study.

\section{Literature Review}

\section{Dual Education in Slovakia}

Dual education is a system of vocational education and training, which is characterized in particular by a close link between general and vocational theoretical education and practical training at a particular employer, as cited in (Neupauerová, 2013). Čaplovič (2013) writes, that a dual system can be defined as a systematic link between theoretical instruction and practical training while ensuring great efficiency. In the enterprise, the pupil learns how to cope with the changing requirements of corporate practice, but also learns how different social relationships exist in the work environment. The pupil is supported by independence and responsibility.

According to Kováč (2014) and Zmeková \& Lukáčová (2019), teaching at school alternates with practical teaching at the employer's premises. It can be weekly, biweekly, monthly or even several months of practical lessons. Dual education thus ensures that the education and training of the pupil fully meets the requirements of the employer's practice. Practical training at the employer takes place in practical training centers or in the employer's premises. The centers and workplaces are included in the network of schools administered by the Ministry of Education. Depending on the technical and technological focus of the employer's activity, part of the VET may also take place at several employers' workplaces or at several VET centers, which may be the secondary vocational school itself or a practical training center or a practical training center established by an employer or group of employers. The Center of Vocational Education and Training disposes of comprehensive material and technical provision of practical education in the extent of the entire content of practical education. Dual education is not only profitable for pupils and employers, but also for secondary vocational schools and the teachers themselves. Dual education - a combination of a theory and practice - can be applied in both 
vocational and study fields at all levels of education provided by secondary vocational studies. Schools involved in dual education adapt school education programs to the requirements of employers.

Jurkovičová et al (2015) or Gura \& Rošteková (2018) characterize the dual education system as part of the vocational education and training system, which is based on:

- the contractual relationship,

- on the practical training of the pupil directly at the employer,

- on the workplace of practical teaching,

- the financing of the practical training by the employers.

Vasil'ová et al. (2013), Kolláriková (2014) or Bursová (2019) state that a dual education system cannot exist without financial support from the economic practice, which is in the role of employers in dual education. The Slovak education system is based on the principle of almost full public funding of education. As a result, pupils complete their studies only at school and do not experience a real working life. These pupils have a wide range of theoretical knowledge but are not ready for working relationships. A well-designed dual system will not only provide the pupil with the opportunity to develop their knowledge and experience but will also create the preconditions for promoting design and innovation in practice and school in the form of innovative ideas and suggestions.

Even a secondary vocational school wishing to enter the dual education system must carry out its activities in the area of vocational education and training in accordance with the objectives and tasks of the secondary vocational school which is entitled to use the designation Center of Vocational Education and Training, states Košč (2018). An important prerequisite for the school's entry into dual education on the basis of partnership with the employer in the form of a dual education agreement is the modernization and specialization of vocational education and training at school, taking into account labor market needs and employers' requirements. To achieve this, Kováč (2015) claims the school needs active cooperation with the employers' association, professional organization and the employers themselves.

It is also necessary to change the attitude of the general public in order to introduce a dual education system. According to Vasil'ova et al. (2013), the main objective should be to satisfy the requirements of the labor market and graduates. The system should not be set up to satisfy educators. It must be set more pragmatically. When introducing the dual system, education needs to be perceived and set up as part of the labor market and closely linked and adapted to the requirements of institutions in which pupils find real application after graduation. The system must be set up for the needs of Slovakia, because quality education should be a matter for the whole society and for the whole economy.

Kováć (2015) states that a particular employer who, on the basis of his decision to enter dual education, is actively seeking a secondary vocational school for cooperation. For this reason, it is essential for the school to develop, in its own interest, its marketing program and marketing tools, which it publishes on its website. A significant impact on the school's success in entering dual education, according to Kováč (2015) and Košč (2018), is:

- setting the parameters of the school educational program,

- the transparency of information on the offer of study fields,

- the composition and expertise of teachers who teach vocational subjects and Masters of vocational education,

- the technical support of the theoretical education section, which is intended for theoretical vocational education and practical education,

- other information of interest to the employer,

- the expertise of school leaders in the sector that will be focused on dual education.

In order to actively cooperate in meeting the employer's expectations in recruiting pupils for the conclusion of a learning contract, the school must also actively cooperate with the primary school. Among the most successful tools for recruiting pupils were in practice activities of secondary vocational schools, which focused on the demonstration of occupations, excursions at employers, organizing technical circles at school or directly at employers with the support of the school and the like.

\section{Social Partnership in the Czech Republic}


The cooperation of vocational schools with partners is also called social partnership, states Skalková (2017). It is based on the principle that the school should cooperate with its surroundings. The autonomy of schools enables them to adapt their activities to their surroundings and also to the needs of enterprises in order to improve the teaching process as much as possible. The links between the social partners depend on the economic situation of the state and on the existence of important enterprises in the region, claims Knecht (2011). Working with school partners also means that its activities are not detached from reality. How the school provides quality services is also dependent on the intensity of cooperation with the social partners, with the school's main social partners being, as cited in Petrovič (2011) and Průcha (2019):

- employers in the form of small, medium and large enterprises,

- labor offices,

- colleges and universities,

- state administration and self-government,

- school founder,

- the pupil's family.

The partnership takes a variety of forms, states Nová (2016), which may include analyzing the situation on the labor market, identifying the requirements of the workforce, excursions to modern workplaces, providing practical training in modern operations, organizing pupils' competitions, and so on. Here we can state that this relationship of subjects is beneficial for all partners involved.

The most important social partners of vocational schools are those related to the labor markets, as these partners participate in training in the form of vocational training in the current modern technical and technological environment. It is a way for pupils to add practical knowledge and skills to their theoretical knowledge. However, the school needs to be aware of the benefits it can bring to its partners and define their long-term intention accordingly, so that the partners are interested in working together. For schools, Petrovič (2011) states that a partnership means a contribution that is important for an appropriate educational climate in the future. It is in the interest of the whole society to support these activities.

The pedagogical principle of combining theory with practice is fulfilled precisely by the cooperation of the school with enterprises in its neighborhood. Effective vocational training requires partners to be involved in school activities in developing educational programs. Specific cooperation belongs to the content of the school educational program of the school. It is important that cooperation is not only a formal matter but also an essential element in the educational function of the school, states Müller (2009) and Toffler \& Toffler (2007).

Employers in the region are among the most important partners of vocational schools, as these schools produce graduates applying for a job, states Barták et al. (2008). As stated in the White Paper (2001) or in Havlíčková (2015), the need for cooperation to create a quality learning environment has been a focus of competent authorities in the past. The National Training Program in the Czech Republic provides a range of measures, including the establishment of a communication structure with businesses. The White Paper (2001) is the basis laid down in the Education Act, which addresses the issue of secondary school graduates coming from schools to work. In order to make the transition as unproblematic as possible so that graduates are well prepared in the field of work, the White Paper sets out some points to facilitate this transition. Emphasis is placed on:

- implementation of the social partnership,

- participation of representatives of the sphere of work in the final examinations,

- months of practice,

- advice,

- development of information systems on employers' requirements,

- questions of unemployed and unqualified young people.

\section{Analysis and Comparison of Cooperation between Enterprises and Schools}

Cooperation between Schools and Enterprises in the Zlin Region

The objective of the questionnaire survey in the Zlín Region is to find out and evaluate the importance of cooperation with enterprises for schools, to find out how schools cooperate with enterprises in the region, what are the attitudes of schools towards graduates and whether schools use information about their graduates on the labor market feedback of their activities. 
As mentioned above, we have chosen a questionnaire survey as a research method, with a survey as a main research tool. It contained 18 items mapping the issue of cooperation of secondary vocational schools with enterprises in the Zlín Region. Four questions were aimed at identifying the importance of cooperation, ten items map out the forms of cooperation with enterprises, and four items are aimed at the establishment of relationships between schools and their graduates. All items are closed, twelve items are dichotomous, five items are scaled, and one allows you to select one of the listed options.

The questionnaire was addressed to 59 secondary schools in the Zlín Region, the return rate was $89 \%$, which represents 53 schools.

The results of the questionnaire survey can be summarized in the following statements:

- For school management, the cooperation with enterprises is important and considered as an important factor in the educational process. There was no negative assessment in the questionnaires and all respondents replied that they considered cooperation to be an important factor.

- Only one-third of respondents expressed their satisfaction with regard to the legal standards governing possible cooperation between schools and enterprises. On the contrary, two-thirds of respondents consider the legislative conditions to be insufficient.

- Given that most schools consider cooperation with enterprises to be important, we have also assumed that this cooperation will be sufficiently exploited. Our assumption has been fulfilled because most schools use and cooperate with enterprises to carry out on-site training in companies.

- The number of enterprises cooperating with schools varies. Most schools work with eleven or more partners.

- An interesting option for enterprises is to work with schools to develop school education programs, as enterprise representatives have the opportunity to reflect their needs and needs in these programs, but this option is not sufficiently utilized.

- It is also important that schools have a maximum interest in information on how successful pupils are in the workplaces of companies in vocational training and what skills they have and what they achieve.

- A relatively used form of cooperation is the participation of enterprise representatives in final examinations, up to three quarters of schools. However, only half of the schools take advantage of the opportunity to improve their teaching staff at the workplaces of partner enterprises.

- Schools are interested in its graduates even after leaving the school and the focus is on the employment of graduates in the enterprises in which they have been trained, but also on how the graduates have worked in the labor market

\section{Cooperation of Schools and Enterprises in the Žilina Region}

We carried out a similar questionnaire survey in Slovakia in the Žilina Region as we did in the Zlín Region.

Its objective was to identify what are the possibilities of cooperation of secondary vocational schools with enterprises in the Žilina Region. By means of partial objectives, we wanted to find out the benefits of cooperation for enterprises, the benefits for schools and the benefits for the pupils themselves. In the framework of the questionnaire survey, we were particularly interested in the opinion of the benefits of dual education for the company, school and pupil.

The survey was attended by 30 teachers, 60 pupils, 3 representatives of KiaMotors Slovakia, 3 representatives of the subsidiary Mobis Slovakia, which manufactures and sells parts, components and accessories for motor vehicles, representatives of HolidayInn hotels, Dubná Skala and Hotel Slovakia. A total of 99 questionnaires were distributed and completed. We deliberately chose respondents who already have their own dual learning experience, albeit only in the preparatory or validation phase. All schools are involved in a project where activities are undertaken to implement dual education and to adapt vocational training to employers' requirements. The results of the questionnaire survey can be summarized in the following tables (Table 1 - Table 3).

\section{Conclusion}

In our opinion, improving the quality of vocational training is also important for the labor market, as more well-prepared school graduates are more likely to be employed. 
The importance of cooperation between vocational schools and enterprises in preparing young people for their professional life is that the knowledge that pupils acquire at school is not sufficient for a person's further professional life. The environment in which pupils acquire knowledge, habits, knowledge needs to be expanded with another social space, which brings the possibility of "learning to know" in the education of a person. However, training needs to be in the spirit of the present, writes Chvátalova et al. (2012)

\begin{tabular}{||l|c|c|c|}
\hline \multicolumn{1}{|c|}{ Table 1: Benefits of dual education for pupils } \\
\hline Benefits of dual education for pupils & $\begin{array}{c}\text { \% teacher } \\
\text { statement }\end{array}$ & $\begin{array}{c}\text { \% pupil } \\
\text { statement }\end{array}$ & $\begin{array}{c}\text { \% enterprises } \\
\text { statement }\end{array}$ \\
\hline Working on the European labor market & 40 & 25 & 100 \\
\hline Investment in education & 90 & 37 & 22 \\
\hline Higher wage & 40 & 82 & 44 \\
\hline Better working perspectives & 90 & 42 & 78 \\
\hline Higher self-confidence & 80 & 30 & 22 \\
\hline Skills development & 60 & 30 & 67 \\
\hline High professional expertise & 70 & 42 & 67 \\
\hline Improving of communication, teamwork & 40 & 17 & 44 \\
\hline Solving problems directly in practice & 93 & 15 & 78 \\
\hline Improving of motivation & 60 & 52 & 56 \\
\hline $\begin{array}{l}\text { Working experience facilitating entry into } \\
\text { the labor market }\end{array}$ & 70 & 23 & 100 \\
\hline Sourc: Aunhor & & \\
\hline
\end{tabular}

Source: Author

\begin{tabular}{|l|l|c|c|}
\hline \multicolumn{1}{|l|}{ Table 2: Benefits of dual education for enterprises } \\
\hline \multicolumn{1}{|c|}{ Benefits of dual education for pupils } & $\begin{array}{c}\text { \% teacher } \\
\text { statement }\end{array}$ & $\begin{array}{c}\text { \% pupil } \\
\text { statement }\end{array}$ & $\begin{array}{c}\text { \% enterprises } \\
\text { statement }\end{array}$ \\
\hline Provision of qualified staff & 60 & 32 & 78 \\
\hline Stability of workers & 67 & 25 & 67 \\
\hline Lower costs for enterprises & 40 & 37 & 56 \\
\hline $\begin{array}{l}\text { Efficiency, creativity, independence at } \\
\text { work }\end{array}$ & 50 & 18 & 44 \\
\hline Good reputation of the enterprise & 63 & 25 & 89 \\
\hline $\begin{array}{l}\text { Perform productive work during } \\
\text { training }\end{array}$ & 70 & 30 & 67 \\
\hline $\begin{array}{l}\text { Shorter time to achieve the desired } \\
\text { performance }\end{array}$ & 47 & 15 & 89 \\
\hline Source Authr & & \\
\hline
\end{tabular}

Source: Author

\begin{tabular}{|l|c|c|c|}
\hline \multicolumn{1}{|c|}{ Table 3: Benefits of dual education for school } \\
\hline Benits of dual education for pupils & $\begin{array}{c}\text { \% teacher } \\
\text { statement }\end{array}$ & $\begin{array}{c}\text { \% pupil } \\
\text { statement }\end{array}$ & $\begin{array}{c}\text { \% enterprises } \\
\text { statement }\end{array}$ \\
\hline Better education & 40 & 23 & 67 \\
\hline Strengthening of vocational training & 53 & 13 & 78 \\
\hline $\begin{array}{l}\text { Better cooperation between schools and } \\
\text { enterprises }\end{array}$ & 47 & 17 & 89 \\
\hline Contribution to creativity and innovation & 30 & 10 & 22 \\
\hline $\begin{array}{l}\text { Developing the knowledge and skills of } \\
\text { teachers and masters }\end{array}$ & 60 & 20 & 78 \\
\hline Pupils' interest in admission to school & 47 & 35 & 44 \\
\hline Public interest in school & 60 & 23 & 67 \\
\hline Source: Author & & \\
\hline
\end{tabular}

Source: Author

In our opinion, enterprises could be more involved in the development of school education programs and in this way more effectively apply their requirements, intentions and needs. In the area of improving the teaching staff at the workplaces of partner enterprises, it is also possible to take steps to improve the situation, since the more teachers improve in the business, the more up-to-date they will have the knowledge and experience they can pass on to their pupils. It is also worth considering, in the light of 
the findings, that schools consider sponsorship issues that would allow, for example, the purchase of modern information technology. Schools may also be advised to consistently record data on the employment of their graduates in the labor market in the field, as this information provides important feedback on school activities.

\section{References}

Barták, F., Berný, L., Coufalík, J., Čiháková, H., Husová, Z., Kratochvílová, J., Marinková, H., Mužík, B., Ondrejkovič, P., Peška, J., Pohanková, J., Strádal, J., Vašáková, V., Vencovská, T \& Vojtěch, J. (2008). Partnerships between schools and employers. Praha: Národní ústav odborného vzdělávání.

Bursová, J. (2019). Measures targeted at young people in employment, taking into account the operational program. Disputationes Scientificae Universitatis Catholicae in Ružomberok, 19(1), 43-51.

Čaplovič, D. (2013). Príhovor na medzinárodnej konferencii o duálnom systéme odborného vzdelávania, [Speech at the International Conference on the Dual Vocational Education System], Bratislava. Retrived from <https://www.minedu.sk/prihovorna medzinárodnej konferencii o duálnom systéme odborného vzdelávania-bratislava/> Chvátalová, L., Němeček, M., Franzová, E., Spousta P., Vašková, D. \& Šnýdl, J. (2012). Social partnership through the eyes of employers. Praha: Národní ústav pro vzdělávání, školské poradenské zařízení a zařízení pro další vzdělávání pedagogických pracovníků.

Gura, R., \& Rošteková, M. (2018). French model of professionalization of tertiary education in Slovakia. Politické Vedy, (3), 236-244. https://doi.org/10.24040/politickevedy.2018.21.3.236-244

Havlíčková, D. (Ed.). (2015). Methodology-Competence, Quality, Qualification, (self) Concept: for non-formal education. Praha: Národní institut pro další vzdělávání.

Jurkovičová, A., Žatkovičová, V. \& Fatelová, M. (2015). Methodological guide for the training of instructors within the project Vocational Education and Training for the Labor Market. Bratislava: ŠIOV.

Knecht, P., Šumavská, G., Bartošek, M., Dobešová, Z., Horská, V., Janík, T. \& Novotná, J. (2011). Modern vocational school, Praha: Národní ústav pro vzdělávání, školské poradenské zařízení a zařízení pro další vzdělávání pedagogických pracovníků.

Kolláriková, T. (2014). Education as an important factor of the situation of young people in the labor market. Acta academcia karviniensia, 14(3), 88-98.

Košč, M. J. (2018). The future of the labor market in Slovakia in the context of demographic change and industry 4.0. Budúcnost' Európy: Cesta k post-kapitalizmu?, 56.

Kováč, L. (2015). Dual education system - manual for secondary vocational schools, school founder and employer. Bratislava: ŠIOV.

Law No. 245/2008 Z. z. o výchove a vzdelávaní (školský zákon) a o zmene a doplnení niektorých zákonov [on Upbringing and Education (School Act) and on Amendments to Certain Acts].

Law No.61/2015 Z. z. o odbornom vzdelávaní a príprave a o zmene a doplnení niektorých zákonov. [on Vocational Education and Training and on Amendments to Certain Acts].

Müler, R., Obst, O. \& Prášilová, M. (2009). Cooperation of high school with social partners and school educational program. Olomouc, Trifox.

Neupauerová, Z. (2013). Possibilities of using dual system of education following the model of Austrian and German success. Finančné trhy: odborný mesačník pre teóriu a prax finančných trhov, 1-7.

Nová, J. (2016). Dual career in sport and the necessity of its institutionalization in the Czech Republic. Studia sportiva, 10(1), 76-84. https://doi.org/10.5817/StS2016-1-7

Petrovič, P. (2011). Social partnerships of vocational schools. Praha: Národní ústav odborného vzdělávání.

Průcha, J. (2019). Vocational education systems abroad. Pedagogika, 69(2).

Skalková, J. (2017). Youth education in new contexts. Pedagogická orientace, 12(1), 18-30.

Toffler, A., \& Toffler, H. (2007). Forming a new civilization. Praha: Grada Publishing.

Vasil’ová, M., Krnáčová, P., Drábik, P. Rehák, R. \& Chomová, K. (2013). Innovative university education. EKONÓM: Bratislava.

Zmeková, D., \& Lukáčová, D. (2019). Dual education in Slovakia under new conditions. Journal of Technology \& Information Education, 11(1). https://doi.org/10.5507/jtie.2019.004 